\title{
Evidence that infectious stages of Tetracapsula bryosalmonae for rainbow trout Oncorhynchus mykiss are present throughout the year
}

\author{
M. Gay ${ }^{1, *}$, B. Okamura ${ }^{2}$, P. de Kinkelin ${ }^{1, * *}$ \\ ${ }^{1}$ Institut National de la Recherche Agronomique (INRA), Unité de Virologie et d'Immunologie Moléculaires, \\ Pathologie Infectieuse et Immunité des Poissons, 78352 Jouy en Josas Cedex, France \\ ${ }^{2}$ School of Animal and Microbial Sciences, University of Reading, Whiteknights, PO Box 228, Reading RG6 6AJ, United Kingdom
}

\begin{abstract}
Proliferative kidney disease (PKD) is a hyperplastic condition of the lymphoid tissue of salmonids infected with the spores of Tetracapsula bryosalmonae, a myxozoan parasite formerly designated PKX, which has recently been described as a parasite of several species of bryozoans. The occurrence of PKD is generally associated with seasonal increase in water temperature, with research indicating that transmission of the disease does not occur below 12 to $13^{\circ} \mathrm{C}$. This suggested that the infectious stages are absent from about November to March/April. Here we document the transmission of PKD at water temperatures and seasons previously considered to be non permissive for PKD infection. The exposure of naive rainbow trout Oncorhynchus mykiss (Walbaum) to PKD-infected water ranging from 8 to $13^{\circ} \mathrm{C}$ during the Autumn, Winter and early Spring, resulted in the infection of kidney interstitium once the trout were transferred to $16^{\circ} \mathrm{C}$. In addition, cohabitation studies were conducted with the bryozoan host Fredericella sultana collected from a river at times of low seasonal temperatures because this bryozoan species overwinters as living colonies. Cohabitation of trout with colonies of $F$. sultana in parasite-free city water at $16^{\circ} \mathrm{C}$, also led to renal lymphoid tissue infection with the parasite and even to nephromegaly. Our results provide evidence that the infectious stages of $T$. bryosalmonae for rainbow trout were present in the water throughout the entire year and that the impact of temperature on the development of PKD is primarily a result of the kinetics of Tetracapsula multiplication in bryozoan and fish hosts.
\end{abstract}

KEY WORDS: Trout - Freshwater bryozoan · Parasite $\cdot$ Proliferative disease $\cdot$ Myxosporean · PKX · Tetracapsula $\cdot$ Temperature

\section{INTRODUCTION}

Proliferative Kidney Disease (PKD) (Ferguson \& Needham 1978), is characterised by the strong hyperplastic response of the principal lymphoid tissues of salmonid fish to the developmental stages of a parasite

\footnotetext{
*Present address: Institut Français pour la Recherche et l'Exploration de la Mer (IFREMER), Laboratoire de Pathologie et Génétique des Invertébrés Marins, Ronce les Bains, BP 133, 17390 La Tremblade, France

${ }^{* *}$ Corresponding author. E-mail: kinkelin@jouy.inra.fr
}

until recently of uncertain taxonomy. The causative parasite, designated 'PKX' for 'PKD' organism unknown, had been considered as a putative myxozoan based upon ultra-structural features (Kent \& Hedrick 1985), although no mature spores were observed. Two reviews (Clifton-Hadley et al. 1984, Hedrick et al. 1993) describe features of the disease and the causative agent prior to recently obtained information on the life cycle and taxonomy of the parasite.

PKX is now known as Tetracapsula bryosalmonae (Canning et al. 1999, 2000), a myxozoan parasite of bryozoans which forms, along with the related bryo- 
zoan parasite $T$. bryozoides, a clade distinct from the 2 known orders of the phylum Myxozoa, the Bivalvulida and Multivalvulida (Anderson et al. 1999, Saulnier et al. 1999). Development of the Tetracapsula species takes place within sacs which are free in the coelomic cavity of the bryozoan host (Canning et al. 1999, 2000). The ultrastructure of the spore is unique among myxozoans in that, at maturation, the spore wall is made of 4 flattened cells instead of a hardened shell, otherwise the spore possesses the features common to myxozoans. Known bryozoan hosts for $T$. bryosalmonae include Cristatella mucedo, Plumatella rugosa, Plumatella sp., Pectinatella magnifica and Fredericella sultana (Anderson et al. 1999, Longshaw et al. 1999). If PKX is strictly a parasite of bryozoans, this may in part explain the strong immune response induced when this foreign parasite enters the fish and also why the parasite is unable to complete its development to form mature spores in this apparent 'dead-end' host.

Water temperature was recognized by trout farmers and fish pathologists to be the major environmental factor modulating the severity of PKD. Several investigations have examined the effects of temperature on PKD among fish placed in water from an infected site for 4 to $14 \mathrm{wk}$, followed by their transfer to temperature-controlled laboratory facilities. In some cases fish were later returned to the infected site in order to assess their resistance to infection and development of PKD upon re-exposure.

Exposures of trout to water at $16^{\circ} \mathrm{C}$ for 6 to $7 \mathrm{wk}$ at sites where the disease was regularly observed resulted in the onset of overt PKD. In contrast, fish transferred after exposures in water at 5 to $7^{\circ} \mathrm{C}$ for $4 \mathrm{wk}$ developed no infection as determined by histological examinations of kidney tissues periodically performed throughout the 4 mo following exposure. It was thus concluded that low temperature inhibited the development of the condition (Ferguson 1981).

Additional experiments by Clifton-Hadley et al. (1986) showed that no transmission of PKD occurred in trout held for $4 \mathrm{wk}$ at an infected site, from November to April, when average maximum weekly water temperatures ranged from 8 to $9.6^{\circ} \mathrm{C}$. However, exposure of fish in May, when water temperatures were 14 to $15^{\circ} \mathrm{C}$, resulted in infection but lymphoid hyperplasia was lacking or only mild when the fish were subsequently held at 9 or $12^{\circ} \mathrm{C}$. Transfers after exposure at 14 to $15^{\circ} \mathrm{C}$ to either 15 or $18^{\circ} \mathrm{C}$ resulted in overt PKD. Reexposures of fish $1 \mathrm{yr}$ later demonstrated that groups of fish held at $9^{\circ} \mathrm{C}$ were susceptible to overt disease while those held at $12^{\circ} \mathrm{C}$ were resistant to PKD. Previous studies had shown that fish surviving the condition at regular permissive temperatures $\left(\geq 15^{\circ} \mathrm{C}\right)$, were resistant to secondary challenge with the parasite (Ferguson \& Ball 1979, Ellis et al. 1982)
Foott \& Hedrick (1987) demonstrated that the exposure of naive trout at another PKD-infected site from mid-November to mid-March at average mean monthly water temperatures of $13,11,7,7$ and $10^{\circ} \mathrm{C}$ respectively, failed to develop PKD after transfer to $17^{\circ} \mathrm{C}$ water temperatures. Exposures to the parasite completed during the other months when water temperatures ranged from 12 to $20^{\circ} \mathrm{C}$, all resulted in overt PKD and survivors of infection were shown to have an acquired resistance to the disease.

All of these observations support the hypothesis that PKD should be considered a disease of salmonids in warm water. However, in all of these studies, susceptibility to infection was evaluated by managing water temperature either during or after exposures to the parasite. The fact that infection and disease can occur at lower water temperatures has been previously described (de Kinkelin unpubl., in Hedrick et al. 1993) for the winter of 1990 when an outbreak of PKD was observed in trout held at 'non-permissive' temperatures $\left(10 / 11^{\circ} \mathrm{C}\right)$ from the time of their initial stocking at a fish farm. Nephromegaly was similarly induced among rainbow trout receiving intra-peritoneal injections with high doses of PKX at lower water temperatures (Rafferty 1986).

The effects of water temperature on either the kinetics of parasite propagation and/or the fish's immune response therefore remain uncertain. With the involvement of the bryozoan and the infectious stages for fish now known (Canning et al. 1999, 2000), a more precise understanding of the relationship between presence of these stages, water temperature and the development of PKD is possible. With this objective in mind we initiated novel investigations on the transmission of PKD to fish at periods of the year when water temperatures were not within the ranges hitherto accepted as permissive for this disease, but that took into account the presence of the bryozoan host. The successful transmission of the parasite to trout substantiated the presence of the infectious stages of Tetracapsula bryosalmonae in the water throughout the year when water temperatures were above 7 to $8^{\circ} \mathrm{C}$ and providing the bryozoan host was present in the environment.

\section{MATERIALS AND METHODS}

Fish. The rainbow trout Oncorhynchus mykiss (Walbaum) used in the infection trials were from stocks with no history of PKD. They belonged to trout strains developed by the geneticists of Institut National de la Recherche Agronomique (INRA), and were designated Gournay Automnale Précoce, Printanière and Synthétique respectively (Table 1 ). These fish were reared in ultra-violet-irradiated, dechlorinated recycled city 
water at 10 to $12^{\circ} \mathrm{C}$ in the specific pathogen free (SPF) area of the Fish Experimental Facilities (FEF) at the campus of Jouy en Josas. Fish were fed a dry pelleted ration once daily at $1 \%$ of their body weight.

PKD-infected sites. The first PKD-infected site was a recycled water system (Chilmonczyk et al. 1989) which forms a distinct area of FEF. Since this system supplies raceways, it has been designated Principal Recycled Water System (PRWS). PKD was found in the PRWS $12 \mathrm{yr}$ ago and numerous investigations, including attempts to identify the infective stages of the parasite (Hedrick et al. 1992), have been conducted here. In addition, studies have examined potential invertebrate hosts releasing the parasite (de Kinkelin \& Morris unpubl.).

The specifications of the PRWS are: total water content $180 \mathrm{~m}^{3}$, water flow $60 \mathrm{~m}^{3} \mathrm{~h}^{-1}$, holding facilities for fish in the form of 7 raceways of a total volume of $35 \mathrm{~m}^{3}$. During the latter part of the 1960s the PRWS was supplied by water pumped from the river Bièvre which crossed the campus of Jouy en Josas. This is the presumed origin of the Tetracapsula and bryozoans currently residing in the PRWS.

Since being built, the PRWS has harboured several species of fish but principally salmonids originating from various geographic areas, for various periods of time. This has resulted in the presence of pathogens such as Aeromonas salmonicida, Ichthyophtirius multifiliis and Flavobacterium psychrophilum, resident in carrier fish harboured in the system. These pathogens are often encountered in trout farms, and their presence in the PRWS necessitated specific treatments during infection trials with PKD.
The second PKD-infected site was on a trout farm with a history of PKD for the past 2 decades. The farm is located $75 \mathrm{~km}$ from Jouy-en-Josas; on the river Juine at $48^{\circ} 18^{\prime} 31^{\prime \prime} \mathrm{N}$, and longitude: $02^{\circ} 05^{\prime} 02^{\prime \prime} 3 / 10 \mathrm{E}$. The infection trials at this site were conducted upstream of the outlets of the fish ponds.

Infections trials with PKD. All the infection trials encompassed 2 phases: one phase of fish exposure to parasite and one phase which monitored the progress of infection at water temperatures $\geq 16^{\circ} \mathrm{C}$.

Infection trials in the PRWS: Experimental groups of fish, coded ' $\mathrm{S}$ ' for sentinels, were held for a variable period of time in the PKD-infected water (Table 1). Then, depending on the water temperature, they were either left in this facility, if the water temperature was above $16^{\circ} \mathrm{C}$, or transferred after 3 to $10 \mathrm{~d}$ in the PRWS into thermo-regulated SPF water at $16^{\circ} \mathrm{C}$ (Table 1). This second phase of the trial took place in the infectious disease experimental room, another area of the FEF. A preventive treatment of furunculosis with florfenicol $\left(50 \mathrm{mg} \mathrm{kg}^{-1}\right.$ body weight $\mathrm{d}^{-1}$ ) for $10 \mathrm{~d}$ was orally delivered to the fish on the 5th day post-exposure to parasite. This treatment was delayed in trial $98 \mathrm{~S} 10$, resulting in severe losses from bacterial origin. Two immersion treatments in 1/5000 formalin, delivered for $20 \mathrm{~min}$ at $2 \mathrm{~d}$ intervals once the fish were held at $16^{\circ} \mathrm{C}$, prevented the onset of infection with external protozoans. Water route treatment with quinine (Schmahl et al. 1996) (10 $\mathrm{mg} \mathrm{l}^{-1}$ for $\left.1 \mathrm{~h}\right)$, repeated twice at $4 \mathrm{~d}$ intervals at $16^{\circ} \mathrm{C}$, was used in trial $99 \mathrm{~S} 04$ and later trials, to control ichthyophthiriosis, which had previously been a severe problem in trials $98 \mathrm{~S} 11$ and $99 \mathrm{~S} 02$.

Table 1. Protocol and results of water route infection trials of rainbow trout in PKD-infected indoor recirculating water unit (PRWS)

\begin{tabular}{|c|c|c|c|c|c|c|}
\hline $\begin{array}{l}\text { Trial } \\
\text { code }\end{array}$ & $\begin{array}{l}\text { Exposure initiation } \\
\text { Total duration } \\
\text { (d) }\end{array}$ & $\begin{array}{c}\text { Fish: } \\
\text { No. (weight, g) } \\
\text { Strain }^{\mathrm{a}}\end{array}$ & $\begin{array}{l}\text { Exposure duration }(\mathrm{d}) \\
\text { Water temperature }\left({ }^{\circ} \mathrm{C}\right)\end{array}$ & $\begin{array}{c}\text { Days in } \\
\text { parasite-free } \\
\text { water at } 16^{\circ} \mathrm{C}\end{array}$ & $\begin{array}{l}\text { Time to 1st } \\
\text { record of PKX } \\
\text { in kidney (d) }\end{array}$ & $\begin{array}{l}\text { No. fish } \\
\text { infected/ } \\
\text { examined }\end{array}$ \\
\hline $98 \mathrm{~S} 07$ & $\begin{array}{c}17 \text { Jul } 1998 \\
111\end{array}$ & $\begin{array}{c}36(120) \\
\text { GAP 11/96 }\end{array}$ & $\begin{array}{c}111 \\
16.6-20\end{array}$ & 0 & 32 & $31 / 31$ \\
\hline 98 S 09 & $\begin{array}{c}4 \text { Sep } 1998 \\
70\end{array}$ & $\begin{array}{c}30(125) \\
\text { GAP } 12 / 96\end{array}$ & $\begin{array}{c}70 \\
16.6-18.9\end{array}$ & 0 & 33 & $10 / 10$ \\
\hline $98 \mathrm{~S} 10$ & $\begin{array}{c}16 \text { Oct } 1998 \\
52\end{array}$ & $\begin{array}{c}50(21) \\
\text { GAP 10/97 }\end{array}$ & $\begin{array}{c}10 \\
11.7-16^{\circ} \mathrm{C}\end{array}$ & 42 & 40 & $6 / 16$ \\
\hline 98 S 11 & $\begin{array}{c}21 \text { Nov } 1998 \\
52\end{array}$ & $\begin{array}{c}50(2-4) \\
\text { Print } 04 / 98\end{array}$ & $\begin{array}{c}9 \\
9-12.9\end{array}$ & 43 & 52 & $1 / 1$ \\
\hline $98 \mathrm{~S} 12$ & $\begin{array}{c}29 \text { Dec } 1998 \\
40\end{array}$ & $\begin{array}{c}40(3-6) \\
\text { Print 04/98 }\end{array}$ & $\begin{array}{c}7 \\
9.8-12.1\end{array}$ & 33 & 40 & $4 / 4$ \\
\hline 99 S 02 & $\begin{array}{c}12 \text { Feb } 1999 \\
46\end{array}$ & $\begin{array}{c}36(5-8) \\
\text { Print 04/98 }\end{array}$ & $\begin{array}{c}6 \\
9-11\end{array}$ & 40 & 46 & $4 / 4$ \\
\hline 99 S 04 & 02 Apr 1999 & $\begin{array}{l}70(10-14) \\
\text { Print 04/98 }\end{array}$ & $\begin{array}{c}4 \\
13-14.6\end{array}$ & 77 & 47 & $52 / 70$ \\
\hline 99 S 05 & $\begin{array}{c}25 \text { May } 1999 \\
52\end{array}$ & $\begin{array}{l}50(12-17) \\
\text { Print } 04 / 98\end{array}$ & $\begin{array}{c}3 \\
15.7-17.4\end{array}$ & 49 & 41 & $46 / 46$ \\
\hline
\end{tabular}


Table 2. Protocol and results of infection trials of rainbow trout for PKD in river Juine

\begin{tabular}{|c|c|c|c|c|}
\hline $\begin{array}{l}\text { Trial } \\
\text { code }\end{array}$ & $\begin{array}{l}\text { Exposure } \\
\text { initiation } \\
\text { Total } \\
\text { duration (d) }\end{array}$ & $\begin{array}{c}\text { Exposure } \\
\text { duration }(\mathrm{d}) \\
\text { Water } \\
\text { temperature }\left({ }^{\circ} \mathrm{C}\right)\end{array}$ & $\begin{array}{c}\text { Fish: } \\
\text { No. } \\
\text { (Weight, g) } \\
\text { Strain }^{\mathrm{a}}\end{array}$ & $\begin{array}{l}\text { No. fish } \\
\text { infected/ } \\
\text { examined }\end{array}$ \\
\hline 99 B2 1 & $\begin{array}{c}30 \text { Nov } 1999 \\
58\end{array}$ & $\begin{array}{c}9 \\
7.5-9.2\end{array}$ & $\begin{array}{c}23 \\
(3.1) \\
\text { Print 04/99 }\end{array}$ & $3 / 23$ \\
\hline 00 B2 2 & $\begin{array}{c}21 \text { Jan } 2000 \\
57\end{array}$ & $\begin{array}{c}7 \\
4.5-9\end{array}$ & $\begin{array}{c}25 \\
(9.3) \\
\text { Print 04/99 }\end{array}$ & $0 / 25$ \\
\hline 00 B2 3 & $\begin{array}{c}25 \text { Mar } 2000 \\
59\end{array}$ & $\begin{array}{c}7 \\
10.5-13.5\end{array}$ & $\begin{array}{c}20 \\
(28.7) \\
\text { Print } 04 / 99\end{array}$ & $4 / 19$ \\
\hline
\end{tabular}

Two to $3 \mathrm{~d}$ after the sampling of bryozoans from the river, the infection trials were initiated by transferring the bryozoans into a small plastic cage placed in a 121 flow-through aquarium, holding 25 juvenile rainbow trout at $16^{\circ} \mathrm{C}$ (Table 3). Water was turned off and fish held under static conditions of infection for $16 \mathrm{~h}$ with water aeration. The water flow was then resumed and cohabitation of fish and bryozoans continued. Under such conditions, bryozoans died within 7 to $10 \mathrm{~d}$. Treatments to prevent secondary infections among trout exposed to the bryozoans were implemented as described in previous trials.

Search for source of PKD in the PRWS and the river site. During the past decades at least 25 species of invertebrates but no bryozoans were found in the PRWS. They were all tested separately or as groups, for their possible role in releasing the infectious stages of PKD. By analogy with what was known of myxozoan life cycles to date, the studies had primarily concerned the oligochaete worms living in the system (Hedrick et al. 1993), but all of these experiments to fish, coded B2, were held for 7 to $9 \mathrm{~d}$ in a cylindrical floating cage composed of plastic grid $(25 \mathrm{~cm}$ diameter, $40 \mathrm{~cm}$ height) in the river water before being transferred back to aquaria in the FEF receiving $\mathrm{SPF} 16^{\circ} \mathrm{C}$ water. Water temperature at the farm site was monitored on an oxy-thermometer (Aqualarm, Sedia, Morlaix, France). Three trials were conducted during cold periods of the year (Table 2). Treatments to prevent bacterial and parasitic infections as described above were applied to fish in all 3 trials.

Infection trials with Tetracapsula bryosalmonae-infected bryozoans: The bryozoan, Fredericella sultana, was abundant at the river site growing as colonies attached to the aquatic plant Fontinalis antipyretica. Colonies of $F$. sultana attached to Fontinalis were collected on different dates (Table 3) and brought to the laboratory, where colonies were gathered in Petri dishes for enumeration of zooids using a dissection microscope. Three subsamples of the bryozoan material were then made. The largest subsample was utilized for the infection trial of trout (coded B1) and the 2 others were then used to assay for the presence of $T$. bryosalmonae through visual inspection, using a dissection microscope, and by PCR (see opposite).
Table 3. Protocol and results of the infection trials for PKD conducted by cohabitation of rainbow trout and infected bryozoans. ND: not determined

\begin{tabular}{|c|c|c|c|c|c|}
\hline $\begin{array}{l}\text { Trial } \\
\text { code }\end{array}$ & $\begin{array}{l}\text { Exposure } \\
\text { initiation } \\
\text { Total } \\
\text { duration (d) }\end{array}$ & $\begin{array}{c}\text { Fish: } \\
\text { No. } \\
\text { (Weight, g) } \\
\text { Strain }^{\mathrm{a}}\end{array}$ & $\begin{array}{l}\text { No. } \\
\text { zooids }\end{array}$ & $\begin{array}{c}\text { PCR with } \\
\text { bryozoans, } \\
\text { no. batches } \\
\text { amplified/tested }\end{array}$ & $\begin{array}{c}\text { Occurrence of PKD: } \\
\text { No. fish } \\
\text { infected/tested } \\
\text { (No. nephromegaly) }\end{array}$ \\
\hline 99 B1 1 & $\begin{array}{c}13 \text { Oct } 1999 \\
53\end{array}$ & $\begin{array}{c}25 \\
(5.0) \\
\text { Print } 04 / 99\end{array}$ & ND & $2 / 4$ & $\begin{array}{c}16 / 20 \\
(8)\end{array}$ \\
\hline 99 B1 2 & $\begin{array}{c}23 \text { Oct } 1999 \\
68\end{array}$ & $\begin{array}{c}25 \\
(3.4) \\
\text { Print } 04 / 99\end{array}$ & 82 & $1 / 4$ & $\begin{array}{c}3 / 25 \\
(2)\end{array}$ \\
\hline 99 B1 3 & $\begin{array}{c}1 \text { Dec } 1999 \\
55\end{array}$ & $\begin{array}{c}25 \\
(3.1) \\
\text { Print } 04 / 99\end{array}$ & 129 & $1 / 4$ & $\begin{array}{c}8 / 24 \\
(4)\end{array}$ \\
\hline 00 B1 4 & $\begin{array}{c}10 \text { Jan } 2000 \\
57\end{array}$ & $\begin{array}{c}25 \\
(5.7) \\
\text { Print } 04 / 99\end{array}$ & 179 & $4 / 8$ & $\begin{array}{c}10 / 25 \\
(1)\end{array}$ \\
\hline 00 B1 5 & $\begin{array}{c}15 \text { Feb } 2000 \\
58\end{array}$ & $\begin{array}{c}25 \\
(13.2) \\
\text { Print } 04 / 99\end{array}$ & ND & $3 / 4$ & $\begin{array}{c}1 / 25 \\
(1)\end{array}$ \\
\hline 00 B1 6 & $\begin{array}{l}4 \text { Apr } 2000 \\
55\end{array}$ & $\begin{array}{c}25 \\
(29.5) \\
\text { Print } 04 / 99\end{array}$ & 122 & $4 / 4$ & $\begin{array}{c}2 / 25 \\
(0)\end{array}$ \\
\hline 00 B1 7 & 10 May 2000 & $\begin{array}{c}25 \\
(3.20) \\
\text { Sy } 11 / 99\end{array}$ & 253 & $0 / 4$ & $\begin{array}{c}19 / 24 \\
(15)\end{array}$ \\
\hline
\end{tabular}

${ }^{a}$ Fish strain. Print: Printanière; Sy: Synthétique; 04/99, 11/99: dates of fertilisation 
transmit PKD failed (de Kinkelin unpubl.). Once the role of freshwater bryozoan as host for the agent of PKD was established (Anderson et al. 1999, Canning et al. 1999), devices to trap potential dissemination forms of bryozoans were employed (Petri dishes, screens, pieces of mesh). No bryozoan material was collected from May to November 1999 although all the water volume of the PRWS had passed through a $250 \mu \mathrm{m}$ mesh hundreds of times. In April 2000, the water supply of the PRWS was by-passed for $2 \mathrm{~h}$ allowing an investigation of the contents of the settling tank. The different parts of the settling and pumping devices were rinsed and examined for the presence of bryozoans (living colonies or resistant statoblast stages). Collections of putative bryozoan hosts of $T$. bryosalmonae at the river site were conducted from autumn to early summer.

Monitoring of PKD infection. Clinical signs, necropsy and cytological examinations of trout: During the course of the trials, changes in behaviour and body shape, possible listlessness, melanosis, abdominal dropsy and gill pallor were recorded. After various periods of time (Tables 1 to 3 ), the fish were sacrificed, and monitored for the presence of nephromegaly, splenomegaly or any other abnormality. The presence of the parasite in fish was assessed from renal impression smears stained with May-Grünwald Giemsa and microscopically observed at $200 \times$ magnification. Kidney specimens were also collected and stored for PCR testing.

Searching for myxozoan infections in bryozoans: Bryozoans collected from the farm site (designated infection trial B1: Table 3) were removed from the Fontinalis and colony branches were torn apart in order to encourage release of parasites (Longshaw et al. 1999). Petri dishes containing the bryozoan colonies were then searched for parasite material using a dissection microscope. Spore sacs were gently transferred by pipette onto a microscope slide and observed with an Olympus phase contrast microscope at $\times 400$ to 1000 magnification.

DNA extraction and PCR of bryozoan and fish material: The infection status of Fredericella sultana and the renal tissue from some fish from the infection trials were determined by PCR because visual assessments for Tetracapsula bryosalmonae infection of bryozoans based upon the observation of parasite stages was highly time consuming and generally revealed no apparent infections. Bryozoan material set aside for PCR was divided into 4 sub-groups of $\sim 40 \mathrm{mg}$. Whole kidneys of the fish from trials B2 (Table 2) and B1 (Table 3) were collected (mean fish weights $3.1 \mathrm{~g}$ and $29.5 \mathrm{~g}$ respectively). DNA was extracted by boiling for $15 \mathrm{~min}$ in $500 \mu \mathrm{l}$ of Chelex $^{\circledR} 10 \%$ in an Eppendorf ${ }^{\oplus}$ tube (Walsh et al. 1991). The mixture was then briefly vortexed and centrifuged, and the supernatant was put in a clean sterile Eppendorf tube to be used as stock DNA which was kept at $-20^{\circ} \mathrm{C}$ until use.

Each DNA sample was subject to PCR at 3 dilutions: none, $1 / 10$ and $1 / 100$. The dilutions were made in double distilled water. Samples were amplified using primers PKX0727 (GTT GTG GAC AAA CGC AAG CTC C [forward]) and PKX1032 (CGC TCC TCC AAC TTT CGT TC [reverse]) (Saulnier \& de Kinkelin 1997). The PCR mixture was formulated by adding $40 \mu \mathrm{l}$ of double distilled water, $5 \mu \mathrm{l}$ of PCR buffer $(200 \mathrm{mM}$ Tris$\left.\mathrm{HCl}_{1} 500 \mathrm{mM} \mathrm{KCl}, \mathrm{pH} 8.4\right), 1.5 \mu \mathrm{l}$ of $50 \mathrm{mM} \mathrm{MgCl}_{2}$ solution, $1 \mu \mathrm{l}$ of $100 \mathrm{mM}$ dNTPs, $1 \mu \mathrm{l}$ of each primer solution

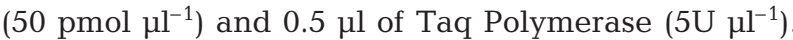
The mixture was vortexed prior to the addition of $2 \mu \mathrm{l}$ of template DNA and of $50 \mu \mathrm{l}$ of mineral oil. The tubes were then placed in a Thermocycler MJResearch programmed as follows: denaturation for 4 min at $94^{\circ} \mathrm{C}, 30$ rounds of $94^{\circ} \mathrm{C}$ for $1 \mathrm{~min}, 54^{\circ} \mathrm{C}$ for $30 \mathrm{~s}$ and $72^{\circ} \mathrm{C}$ for 90 $\mathrm{s}$ and finally extension for $4 \mathrm{~min}$ at $72^{\circ} \mathrm{C}$. The PCR products were then run on a $1 \%$ agarose gel with ethidium bromide. The specificity of the PCR was verified by cloning and sequencing selected products. Briefly, the PCR product was cloned into pER2.1 plasmid (Invitrogen) according to the TOPO TA ${ }^{\circledR}$ cloning protocol (Groningen, Netherlands). Their plasmids were prepared from different colonies using NucleoSpin $^{\circledR}$ extension kit (Mackerey Nagel, Hoerdt, France), and inserts were sequenced with sequencing device ABI 310 (Perkin Elmer, Courtaboeuf, France). Sequences obtained were compared following their alignment with the Genetics Computer Group (1991) program.

\section{RESULTS}

\section{Infections trials in the principal recycled water system (PRWS)}

Overt or sub-clinical PKD was observed in trout from all of the infection trials. This established the year-long presence of the infective stages of the causative agent of PKD in PRWS at least when water temperatures were equal to or greater than $9^{\circ} \mathrm{C}$ during the period of exposure of fish to the parasite (Table 1).

The entire duration of Trials $98 \mathrm{~S} 07$ and $98 \mathrm{~S} 09$ took place in the PRWS because water temperatures exceeded $16^{\circ} \mathrm{C}$ until mid-October, thus enabling the occurrence of overt PKD. All individual fish, from both trials examined for PKX cells in kidney tissue imprints or nephromegaly, were positive and the number of fish deaths due to PKD was 25 and 5 for Trials 98 S 07 and $98 \mathrm{~S} 09$, respectively. We assumed that the prevalence of PKD in these groups was $100 \%$. The survivors of 
these trials were further kept as potential carriers that might be shedding parasites for other experimental purposes.

In Trial $98 \mathrm{~S}$ 10, 36 fish died from furunculosis contracted in the PRWS, within $20 \mathrm{~d}$ following their transfer to $16^{\circ} \mathrm{C}$. Out of the 16 live or dead fish examined, 6 displayed PKX cells in kidney tissue. The analysis of fish from Trial 98 S 11 was severely hindered by an attack of ichthyophthiriosis, again contracted while the fish were in the PRWS. Only 1 fish from this trial survived and it exhibited nephromegaly and PKX cells. In trial $98 \mathrm{~S} 12$ all 4 fish sacrificed $40 \mathrm{~d}$ post exposure to parasite were positive for PKX, suggesting a prevalence of infection higher than $50 \%$ and indeed, 14 of the 36 remaining fish used as putative parasite carriers in separate investigations demonstrated nephromegaly and PKX cells over the subsequent $100 \mathrm{~d}$.

Fish from Trial 99 S 02 were also compromised by ichthyophthiriosis, which killed 32 fish before PKX cells were evident. Four of the remaining fish examined $40 \mathrm{~d}$ post exposure were positive for PKX cells and nephromegaly. As in the experiments reported above experiments, the prevalence of PKD in this fish group was assumed to be greater than $50 \%$. The fish from Trial 99 S 04 underwent a brief attack of furunculosis that was controlled by treatment with florfenicol. Eighteen trout died within 2 wk post exposure to the parasite but all survivors were found to contain PKX cells, and 25 died from this infection with the associated nephromegaly. The prevalence of infection in both this trial and in $99 \mathrm{~S} 05$ was $100 \%$. No mortalities from secondary infections were recorded in this last trial (99 S 05) because preventive treatments with florfenicol and quinine for furunculosis and ichthyophthiriosis, respectively were effective.

The duration of exposure to parasite in the different trials was reduced progressively from $10 \mathrm{~d}$ (98 S 10) to 9, 7 and $6 \mathrm{~d}$ (99 S 99) after demonstrating that shorter exposure times were sufficient to induce infection at low water temperatures. In later trials the exposure was shortened to 3 and $4 \mathrm{~d}$ at higher temperature ranges.

\section{Infection trials in the river Juine}

Fish exposed in the river Juine were sacrificed after 50 to $52 \mathrm{~d}$ in parasite-free water at $16^{\circ} \mathrm{C}$ in the SPF area of the FEF. Parasitic cells were found in the kidney tissue of some fish from Trials 99 B2 1, initiated in late November, and 00 B2 3, initiated in late March, but no infection was found among fish from Trial 00 B2 2, initiated in January (Table 2). However, PCR tests conducted on bryozoans sampled at the same site in January, revealed infection with Tetracapsula bryosalmonae (see further). Data for water temperatures revealed that the January trial was conducted at an average weekly temperature of $7^{\circ} \mathrm{C}$ which was lower than the average weekly temperatures of the other trials (Fig. 1). In Trial 00 B2 3, 5 fish died from an outbreak of ichthyophthiriosis and 3 tested by PCR for the presence of PKX were positive. In order to evaluate the course of PKD in the farmed trout population, 48 fish stocked in late April into the raceways supplied with the river water were randomly sampled on 25 June and checked for nephromegaly and splenomegaly. Twenty of them (32 to $53 \%$ at confidence interval 95\%) had developed renal lesions scores of 1 to 2 (CliftonHadley et al. 1987) showing that the course of the disease was proceeding as during the previous decades.

\section{Infections trials with bryozoans}

All the bryozoans used in infection trials were Fredericella sultana, as this was by far the most abundant bryozoan found throughout the entire study period at the fish farm. With the exception of the bryozoan material collected for the last trial (B1 7), parasitic DNA was amplified from all the samples of bryozoans (Fig. 2). The specificity of the PCR positives was established by cloning and sequencing the DNA amplified from the 2 samples used in Trial series 99 B1 1 and 99 B1 3. The sequences were $100 \%$ similar to the published sequence of the small sub-unit ribosomal RNA gene of PKX (nucleotide sequence No. U70623 in GenBank ${ }^{\mathrm{TM}}$ (Saulnier \& de Kinkelin 1997).

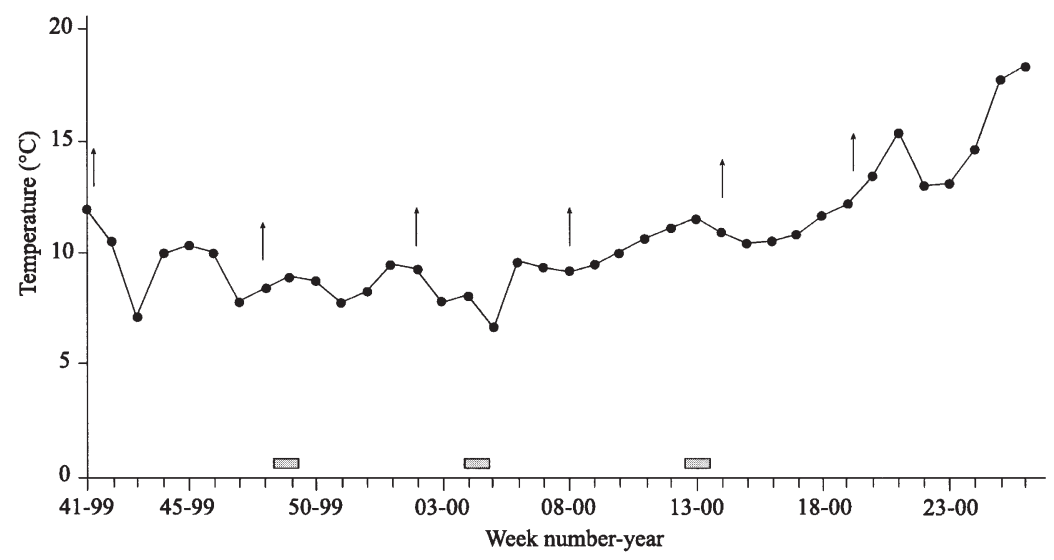

Fig. 1. Curve of mean water temperature of river Juine at site of PKD infection trials, 13 October 1999 to 25 June 2000. Scale bars: dates of exposure of naive rainbow trout to parasites; arrows: dates of sampling of the bryozoans used for the infection trials conducted in aquarium in flow-through city water at $16^{\circ} \mathrm{C}$ 


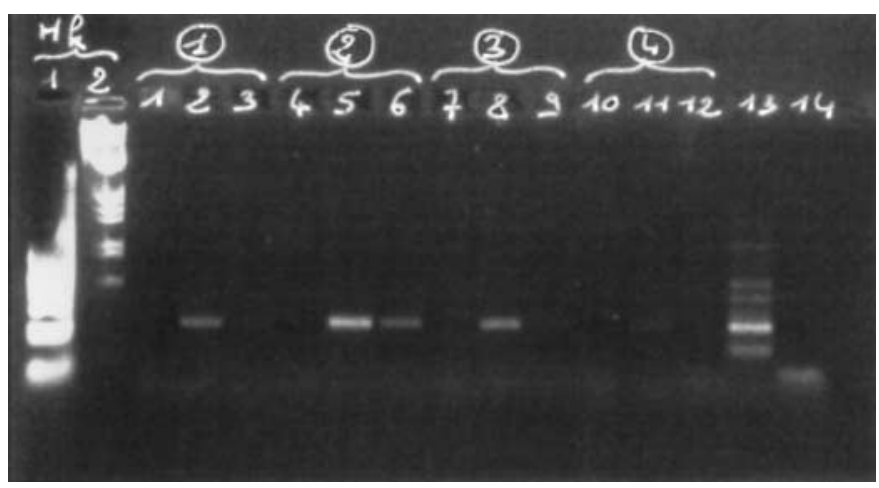

Fig. 2. Electrophoresis on agarose gel of PCR products from bryozoans used for infection trials. Wells 1 to 12: 4 bryozoans samples (1), (2), (3) and (4)), each tested at 3 dilutions $(1 / 1,1 / 10,1 / 100)$. Well 13: positive control on a sample of kidney from infected rainbow trout. Well 14: negative control on distilled water. Mk1 (Well 1) is molecular weight marker pBR322 AluI and Mk2 (Well 2) is molecular weight marker EcoRI + HaeIII

The negative response of the PCR tests performed on bryozoan samples associated with the last trial could have been due to a failure in the DNA extraction process, the presence of Taq inhibitors in the extracted products, or lack of infection in those colonies of Fredericella sultana that were set aside for amplification. The positive DNA control included in our tests was a piece of kidney from infected rainbow trout which gave rise to the expected amplification. PKD occurred in 19 out of 24 trout from this trial (B1 7) with $1 / 3$ of them displaying some degree of nephromegaly, thus indicating that at least some of the F. sultana colonies used in the cohabitation studies were infected with Tetracapsula bryosalmonae.

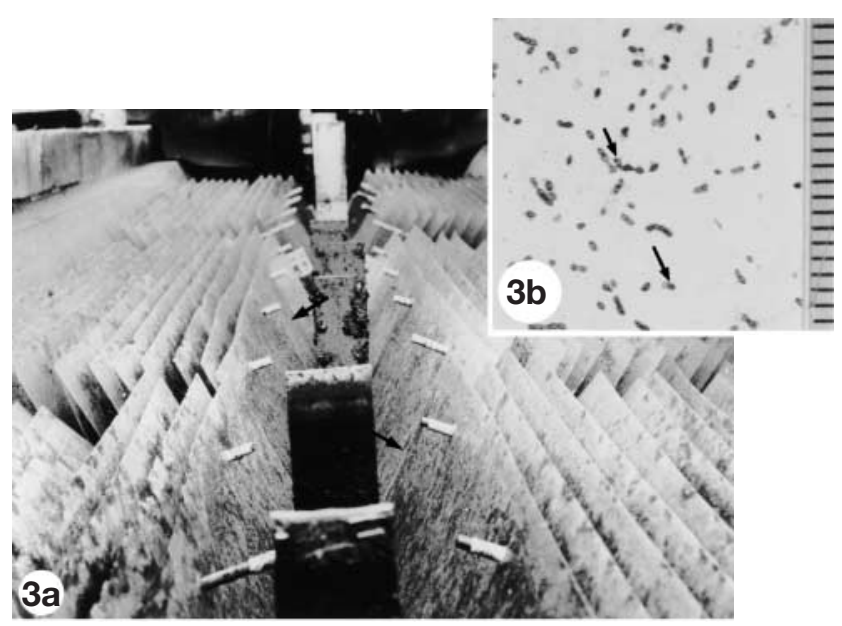

Fig. 3. (a) Fallowed settling tank of the PKD-infected recycled system showing upper side of inclined glassfibre trays (arrows); (b) sessoblasts adhering to lower surface of one tray (arrows). Scale bar intervals $=1 \mathrm{~mm}$
The results of all the infection trials conducted by cohabitation of naive rainbow trout and infected bryozoans are summarised in Table 3. In all the trials, infection of kidney tissue with parasitic cells was detected and nephromegaly occurred in some fish (Table 3). The Fredericella sultana used were thus infected with Tetracapsula bryosalmonae during the entire year, even at low water temperatures (Fig. 1). Despite low sample sizes, regression analysis revealed that the percentage of fish (prevalence) infected with PKD was significantly and positively related to the number of zooids used in each trial (regression of arcsine-transformed proportion of fish infected vs number of zooids per trial: $F_{1,3}=25.79, \mathrm{p}=0.01$ ) (see Table 3).

\section{Putative sources of infective stages in the PRWS and in the river Juine}

An examination of the settling tank of the PRWS in April 2000 demonstrated a muddy layer present on the glassfibre trays arranged in the tank (Fig. 3a). Removal of this layer revealed the presence of numerous sessoblasts (attached statoblasts) on the underside of the trays (Fig. 3b) belonging to an unidentified species of Plumatella. Most of these sessoblasts were empty but some were viable as bryozoans hatched within 2 wk from sessoblasts adhering to small pieces of fibreglass which were excised from colonised areas of the trays and incubated in water at $20^{\circ} \mathrm{C}$. These bryozoans developed zooids typical of Plumatella species (Fig. 4), but specific identifications are precluded due to taxonomic problems for European species within this genus (T. Wood \& B. Okamura unpubl. data). Unfortunately, new colonies hatched from the settling tank trays died within a few days before they could be

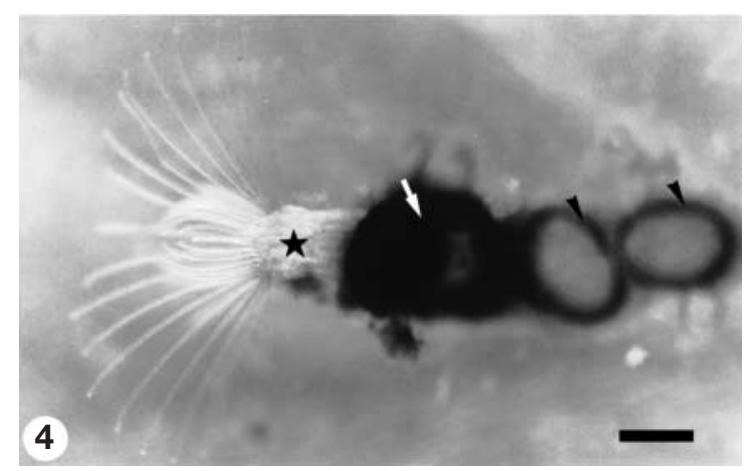

Fig. 4. Plumatella sp. hatching sessoblast from one tray of settling tank. Zooid (star) from 1 hatching sessoblast (arrow); empty sessoblasts stuck to tray surface (arrow heads). Scale bar $=250 \mu \mathrm{m}$ 
examined for Tetracapsula bryosalmonae by PCR. We presume that this Plumatella species contributes to the the presence of PKD in the PRWS.

Prior to mid-June, all bryozoans collected from the river Juine were colonies of Fredericella sultana, which was abundant on the channelized walls of the river leading into the fish farm. However, in mid-June a trip to the site revealed the presence of 2 unidentified species of Plumatella. One species was growing on the undersurfaces of stones and the other infrequently as small colonies very similar in form to $F$. sultana and also growing on Fontinalis. Due to taxonomic problems within the genus Plumatella in Europe, we are not yet able to provide species identifications. Spore sacs similar to those described for Tetracapsula bryosalmonae were found in only a few colonies of F. sultana (Fig. 5). Disruption of these sacs released pluricellular spores measuring $20 \mu \mathrm{m}$ in diameter similar to those of $T$. bryosalmonae (Fig. 6).

\section{DISCUSSION}

The present work constitutes the first report on the transmission of PKD at naturally infected sites under water temperatures and during seasonal periods previously thought to be unsuitable for such transmission. Although in our infection trials the exposure of fish to the parasite lasted 3 to $10 \mathrm{~d}$ at apparently non PKDpermissive temperatures, instead of $4 \mathrm{wk}$ or more as in prior studies (Ferguson 1981, Ferguson \& Ball 1979,

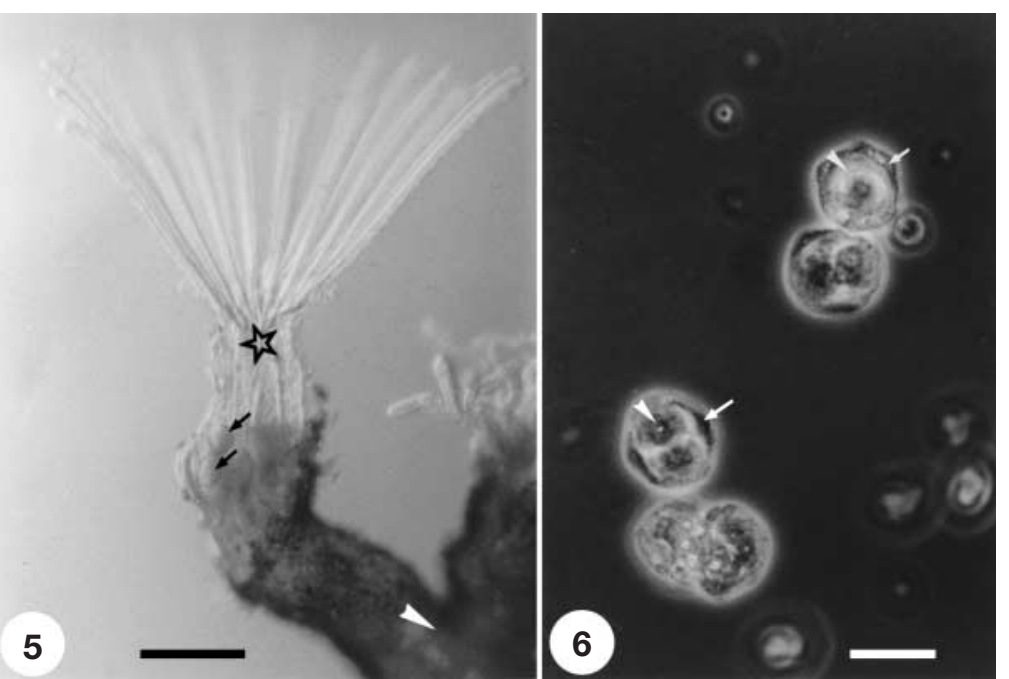

Figs 5 \& 6. Fig. 5. Fredericella sultana, bryozoan from the river Juine used in PKD infection trials performed with rainbow trout. Zooid with extended tentacular crown (lophophore) (star); presumptive spore sacs (arrows) of Tetracapsula bryosalmonae; bryozoan colony (arrow head). Scale bar $=250 \mu \mathrm{m}$ Fig. 6. Spores of Tetracapsula bryosalmonae released from spore sacs of Fredericella sultana. Sporoplasmic cells (arrow heads); valve cells (arrows). Scale bar $=20 \mu \mathrm{m}$
Clifton-Hadley et al. 1986, Ellis et al. 1982), all of our trials but 1 resulted in the transmission of PKD. Our results thus provide evidence that the infectious stages of Tetracapsula bryosalmonae for rainbow trout are present in the water throughout the entire year.

Infection trials conducted in the PRWS were all successful when the average minimum water temperature was $9^{\circ} \mathrm{C}$ or greater, indicating that within such a temperature range the infectious stages of parasite were produced by their bryozoan host(s) present in the system. The trials conducted in the river Juine further confirm that the parasite can multiply even at temperatures as low as $8^{\circ} \mathrm{C}$. Although establishing the prevalence of infection in trout was not the main objective of our study, it was obviously lower in the trials performed in river water than in the ones performed in the PRWS.

There are 3 potential reasons that may account for the differences observed between exposures in the PRWS and the river. Firstly, the dilution of the spores released by bryozoans was probably higher in river water than in the PRWS water. Secondly, recirculation of the water in the PRWS is renewed at only $60 \mathrm{~m}^{3} \mathrm{~h}^{-1}$ out of a total volume of $180 \mathrm{~m}^{3}$. Given the estimated 12 to $15 \mathrm{~h}$ duration of the infectivity of parasites in the water (not shown here), this allows 1 infectious stage to have at least 4 encounters with 1 target fish instead of 1 encounter for the fish held in the floating cage in the river. Thirdly, the average water temperature was higher in the PRWS than in the river water, especially from November to April.

The failure of the second infection trial in the river water (Trial 00 B2 2: Table 2) might have been due to temperatures below the threshold needed for the multiplication of Tetracapsula in the bryozoan host. The average weekly temperature of $7^{\circ} \mathrm{C}$, and the associated shortterm fluctuations experienced during this trial, corresponded to the lowest temperatures monitored between October and June. Daily fluctuations in water temperature during the trial ranged from 7 to $8.5^{\circ} \mathrm{C}$ during the first $4 \mathrm{~d}$ and then attained levels of 6 to $7.5,6$ to 7.5 and 4.5 to $5.5^{\circ} \mathrm{C}$ on the 5 th, 6 th and 7 th days, respectively. Due to nycthemerons, the lowest values of temperature lasted longer than the highest.

In contrast, cohabitation infection trials all resulted in infection of fish with PKD, and the prevalence of infection was significantly related to the number of zooids used. These results indicate that infected bryozoans collected at apparently non 
permissive water temperatures for the multiplication of the parasite can attain infectivity status after being held for 2 to $3 \mathrm{~d}$ at $16^{\circ} \mathrm{C}$, i.e. 32 to $48 \mathrm{~d} \times$ degrees. Presumably, during this short period, infective parasite stages are produced. Similar behaviour is likely under natural conditions, providing the minimum average temperature is $\geq 8^{\circ} \mathrm{C}$.

These results suggest that an average water temperature of 7 to $8^{\circ} \mathrm{C}$ causes a cessation of Tetracapsula bryosalmonae multiplication in the bryozoan host. Such a temperature dependency of parasitic infection in invertebrate hosts is consistent with patterns of parasite development previously reported in fish. No parasitic development occurred in trout exposed to the parasite at permissive temperature for $4 \mathrm{wk}$, after they were held at 5 to $7^{\circ} \mathrm{C}$ for a further 7 mo (Ferguson 1981). It thus seems reasonable to assume that water temperature primarily impacts the multiplication of $T$. bryosalmonae whether in the bryozoan or the fish. Furthermore, our results suggest that the intensity of the fish's immune reaction depends more on the amount of foreign material encountered than on water temperature. The verification of this hypothesis will require a quantitatively reproducible challenge method conducted at water temperatures $<10^{\circ} \mathrm{C}$, either via the water-route once predictable parasite numbers can be harvested from bryozoans, or by parenteral injection with known high doses of PKX cells. Indeed, when held at $12^{\circ} \mathrm{C}$, fish that had been infected for $4 \mathrm{wk}$ at a permissive temperature had already accumulated a sufficient number of parasites so that the lower multiplication of parasites at $12^{\circ} \mathrm{C}$ was still able to induce a hyperplastic cellular response from infected fish (Clifton-Hadley et al. 1986). At present, it cannot be determined at which level, parasite propagation or fish response, water temperature mainly modulates the severity of PKD infection. Nevertheless, a temperature increase certainly accelerates the kinetics of the immune response in the fish, but it would appear that this response primarily requires a sufficient temperaturedependent multiplication of parasite in fish tissues.

There is a major discrepancy between our present results and previous reports of the seasonal absence of infectivity at given sites (Clifton-Hadley 1986, Foott \& Hedrick 1987). This infectivity depends on the presence of infectious stages of the parasite released by bryozoans, and prior studies were conducted in the absence of this knowledge. The often high levels of spatial and temporal variation in the nature and abundance of bryozoan populations at a given site (Okamura \& Hatton-Ellis 1995, Vernon et al. 1996) may help to explain differences amongst sites. Furthermore, Fredericella sultana is the only bryozoan that overwinters as live colonies; all other bryozoans overwinter as statoblasts in regions where PKD develops. Thus, the development of PKD will necessarily reflect the seasonal availability of the particular bryozoan hosts present in the system. Finally, surveys suggest notable spatial and temporal variation in infection by Tetracapsula bryosalmonae (Okamura et al. 2001) in bryozoan populations at numerous sites, and this variability may also help to explain differences amongst studies.

It is becoming clear from transmission trials and PCR (this study) and from extensive sampling of colonies from numerous sites with PKD (Okamura unpubl. data) that visual inspection of colonies is probably an unreliable method of ascertaining the presence of Tetracapsula bryosalmonae in bryozoan populations. In many instances, the proportion of colonies possessing recognizable parasitic sacs is extremely low, and thus absence of sacs as ascertained by visual inspection may not signify absence of the parasites in bryozoan populations. In addition, as we know nothing of the early stages of development nor of the timing of developmental stages in bryozoans, it may be that prevalence levels are much higher than levels based on the presence of recognizable sacs in bryozoan colonies. Ongoing studies of the development of $T$. bryosalmonae in its bryozoan hosts will contribute greatly to understanding these issues. Other issues that remain to be resolved include determining whether $T$. bryosalmonae may cycle between different bryozoan host species, the relationship between host abundance and prevalence of infection, and whether there may be different strains of $T$. bryosalmonae that are suited to different ecological conditions as is suggested by variation in sequence isolates (Okamura et al. 2001). Such information may mitigate the impact of $\mathrm{PKD}$ on fish production, through helping to identify the conditions under which stocking at non-permissive temperatures could be more fully exploited as a means to manage PKD (Ferguson \& Ball 1979, Ferguson 1981, CliftonHadley 1986, Foott \& Hedrick 1987).

Acknowledgements. This work was supported in part by an INRA Masters studentship (M.G.), a grant from the Fédération Française d'Aquaculture, (C 13064 to P.K.), and a grant from the Natural Environment Research Council, UK (GR9/04271 to B.O.). The excellent technical assistance of Bénédicte Loriot from the Unité de Virologie et d'Immunologie Moléculaires, is especially acknowledged. Alexandra Leroux, also from the above research unit, was helpful during the first part of our investigations. Thanks are due to to Céline Urien, Gérard Fayemendy, Eric Letellier and Frank Tiquet from the Fishery Experimental Facilities, for surveillance and maintenance of the experimental fish. Finally, this work could not have been completed without the valuable co-operation of Mr Alain Lubin, Moulin de Glaires 91660 Méréville, who kindly hosted our field studies and numerous visits in his trout farm premises, and who monitored the water temperature of the river. We are indebted to Professor RP Hedrick, University of California, Davies, USA, for his helpful comments on the final draft of this manuscript. 
Addendum. After the termination of the present study, the taxonomic problems which precluded the species identification of the Plumatella zoids present in the PRWS were overcome, and this bryozoan was identified by T. Wood as being Plumatella repens. Similarly, the bryozoan resembling Fredericella, which grew on the undersurface of the stones and on Fontinalis in the river Juine, was identified as being Plumatella emarginata. The valuable contribution of Tim Wood is warmly acknowledged.

\section{LITERATURE CITED}

Anderson CL, Canning EU, Okamura B (1999) Molecular data implicate bryozoans as hosts for PKX (Phylum Myxozoa) and identify a clade of bryozoan parasites within the Myxozoa. Parasitology 119:555-561

Canning EU, Curry A, Feist SW, Longshaw M, Okamura B (1999) Tetracapsula bryosalmonae n.sp. for PKX organism, the cause of PKD in salmonid fish. Bull Eur Assoc Fish Pathol 19:203-206

Canning EU, Curry A, Feist SW, Longshaw M, Okamura B (2000) A new class and order of myxozoans to accommodate parasites of bryozoans with ultrastructural observations on Tetracapsula bryosalmonae (PKX organism). J Eukaryot Microbiol 47:456-468

Chilmonczyk S, Thomas P, de Kinkelin P (1989) Occurrence of proliferative kidney disease in an indoor recirculating unit and indirect experimental contamination of the rainbow trout. Bull Eur Assoc Fish Pathol 9:38-41

Clifton-Hadley RS, Bucke D, Richards RH (1984) Proliferative kidney disease of salmonid fish: a review. J Fish Dis 7: 363-377

Clifton-Hadley RS, Richards RH, Bucke D (1986) Proliferative kidney disease (PKD) in Rainbow trout Salmo gairdneri: further observations on the effects of water temperature. Aquaculture 55:165-171

Clifton-Hadley RS, Bucke D, Richards RH (1987) A study of the sequential clinical and pathological changes during proliferative kidney disease in rainbow trout Salmo gairdneri Richardson. J Fish Dis 10:335-352

Ellis AE, McVicar AH, Munro ALS (1982) A preliminary report on the epidemiology of proliferative kidney disease in brown trout (Salmo trutta) and Atlantic salmon (Salmo salar) in Scotland. Bull Eur Assoc Fish Pathol 2:13-15

Ferguson HW (1981) The effect of water temperature on the development of proliferative kidney disease in rainbow trout Salmo gairdneri Richardson. J Fish Dis 4:175-177

Ferguson HW, Ball HJ (1979) Epidemiological aspects of proliferative kidney disease amongst rainbow trout, Salmon gairdneri Richardson in Northern Ireland. J Fish Dis 2: 219-225

Ferguson HW, Needham EA (1978) Proliferative kidney dis-

Editorial responsibility: Wolfgang Körting,

Hannover, Germany ease in rainbow trout, Salmo gairdneri Richardson. J Fish Dis 1:91-108

Foott JS, Hedrick RP (1987) Seasonal occurrence of the infectious stage of proliferative kidney disease (PKD) and resistance of rainbow trout, Salmo gairdneri Richardson, to reinfection. J Fish Biol 30:477-483

Genetics Computer Group (1991) Program manual for the GCG package, Version 7, April 1991. GCG Madison, WI, USA

Hedrick RP, Monge D, de Kinkelin P (1992) Transmission of PKX, the causative agent of proliferative kidney disease (PKD) to rainbow trout Oncorhynchus mykiss following filtration of water and sediments. Dis Aquat Org 14: $237-240$

Hedrick RP, MacConnell E, de Kinkelin P (1993) Proliferative kidney disease of salmonid fish. In: Faisal M, Hetrick FM (eds) Annual review of fish disease: 3. Pergamon, Elsevier Sciences, Oxford, p 277-290

Kent ML, Hedrick RP (1985) PKX, the causative agent of Proliferative Kidney Disease (PKD) in Pacific salmonid fishes and its affinity with the Myxozoa. J Protozool 32:254-260

Longshaw M, Feist SW, Canning EU, Okamura B (1999) First identification of PKX in bryozoans from the United Kingdom-molecular evidence. Bull Eur Assoc Fish Pathol 19: 146-149

Okamura B, Hatton-Ellis T (1995) Population biology of bryozoans: correlates of sessile, colonial life histories in freshwater habitats. Experientia 51:510-525

Okamura B, Aderson CD, Longshaw M, Feist SW, Canning EU (2001) Patterns of occurrence and 18SrDNA sequence variation of PKX (Tetracapsula bryosalmonae), the causative agent of salmonid proliferative kidney disease. J Parasitol 87:379-385

Rafferty MD (1986) The influence of temperature on experimentally induced proliferative kidney disease. $\mathrm{PhD}$ thesis, National University of Ireland, Cork

Saulnier D, de Kinkelin P (1997) Polymerase chain reaction primers for investigations on the causative agent of proliferative kidney disease of salmonids. J Fish Dis 20:467-470

Saulnier D, Philippe H, de Kinkelin P (1999) Molecular evidence that the proliferative kidney disease organism unknown (PKX) is a myxosporean. Dis Aquat Org 36: $209-212$

Schmahl G, Schmidt H, Ritter G (1996) The control of ichthyophthiriasis by a medicated food containing quinine: efficacy tests and ultrastructure investigations. Parasitol Res 82:697-705

Vernon JG, Okamura B, Jones CS, Noble LR (1996) Temporal patterns of clonality and parasitism in a population of freshwater bryozoans. Proc R Soc Lond B 263:1313-1318

Walsh PS, Metzger DA, Higuchi R (1991) Chelex ${ }^{\circledR} 100$ as a medium for simple extraction of DNA for PCR-based typing from forensic material. Biotechniques 10:506-513

Submitted: December 15, 2000; Accepted: February 19, 2001 Proofs received from author(s): July 25, 2001 